\title{
Arthroscopic Lunotriquetral Ligamentoplasty, from the Cadaver Lab to the Clinical Practice
}

\section{Ligamentoplastia lunotriquetral artroscópica, de la sala de disección a la práctica clínica}

\author{
Marcos Cruz-Sánchez ${ }^{1,2}$ Cristóbal Martínez-Andrade ${ }^{2}$ \\ ${ }^{1}$ Orthopedic Surgery and Traumatology Service, Hospital Dos de Maig \\ - Consorci Sanitari Integral, Barcelona, Spain \\ 2 Trauma Unit, Centro Médico Teknon, Barcelona, Spain \\ Address for correspondence Marcos Cruz Sánchez, PhD, Servicio de \\ Cirugía Ortopédica y Traumatología, Hospital Dos De Maig - Carrer del \\ Dos de Maig 301, 08025, Barcelona, Spain, Barcelona, España \\ (e-mail: marcoscruzsanchez85@gmail.com). \\ Rev Iberam Cir Mano 2021;49(2):e121-e127.
}

\begin{abstract}
Keywords

- lunotriquetral instability

- wrist arthroscopy

- ligamentoplasty

Introduction There has been an increase in the diagnosis of injuries to the intrinsic ligaments of the wrist due to the more widespread use of arthroscopy in the treatment of patients with musculoskeletal wrist pain, and arthroscopy is particularly very helpful to determine the etiology of these lesions at the ulnar level. The treatment of lunotriquetral ligament injuries encompasses different techniques with results that are little reproducible. Ligament reconstruction through tendon grafting has shown favorable results, but it involves extensive open approaches that lead to a slower recovery a lower range of joint motion due to the excess of scar tissue. The objective of the present study is to describe the performance, in a cadaver, of a minimally-invasive lunotriquetral and secondary-stabilizer ligamentoplasty and its application in a representative clinical case.

Material and Methods A preliminary study of six specimens in which a lunotriquetral and secondary-stabilizer ligamentoplasty was performed consecutively through a free tendon graft with arthroscopic assistance. We proceeded to recreate the complete ligament injury, and to perform an assessment of lunotriquetral instability according to the Geissler classification and an arthroscopic ballottement test. We describe the surgical technique, ligament stability after the ligamentoplasty, and the subsequent anatomical dissection, assessing the anatomical structures susceptible to iatrogenic injury. We also describe the application of the technique in one case, comparing the clinical parameters before and after the procedure: range of motion of the joint, strength, pain and the shortened version of the Disabilities of the Arm, Hand, and Shoulder (QuickDASH) questionnaire.

Results The ligamentoplasties performed showed recovery of the stability of the lunotriquetral interval assessed according to the Geissler classification and the arthroscopic ballottement test. In the dissection of the specimens, no iatrogenic lesions were found in the tendons or the surfaces of the mediocarpal and radiocarpal joints. The average
\end{abstract}

received

July 18,2021

accepted

August 23, 2021
DOI https://doi.org/ 10.1055/s-0041-1740093. ISSN 1698-8396. (c) 2021. SECMA Foundation. All rights reserved.

This is an open access article published by Thieme under the terms of the Creative Commons Attribution-NonDerivative-NonCommercial-License, permitting copying and reproduction so long as the original work is given appropriate credit. Contents may not be used for commercial purposes, or adapted, remixed, transformed or built upon. (https://creativecommons.org/ licenses/by-nc-nd/4.0/)

Thieme Revinter Publicações Ltda., Rua do Matoso 170, Rio de Janeiro, RJ, CEP 20270-135, Brazil 


\section{Resumen}

\section{Palabras clave}

- inestabilidad lunotriquetral

- artroscopia de muñeca

- ligamentoplastia distances between the nearest bone tunnels and nerves were of $7.3 \mathrm{~mm}$ for the sensory branch of the ulnar nerve, of $3.6 \mathrm{~mm}$ for the posterior interosseous nerve, and of $4.5 \mathrm{~mm}$ for the ulnar neurovascular bundle. No fractures were observed in the tunnelled bones. In the clinical case herein presented, six months after the intervention, there was an improvement in strength and preoperative pain, with a slight decrease in the joint range of motion (15\% compared to the contralateral joint).

Conclusions The lunotriquetral ligamentoplasty herein described could contribute to the biomechanical restoration of the carpus and be an option for recosntruction in selected cases. Its performance through minimally-invasive techniques, and the use of a free tendon graft together with specific rehabilitation should be considered to optimize the outcomes.

Introducción El diagnóstico de lesiones en los ligamentos intrínsecos de la muñeca ha aumentado debido a un mayor uso de la artroscopia en el tratamiento de pacientes con carpalgia, siendo la artroscopia específicamente de gran ayuda para determinar la etiología de estas lesiones a nivel ulnar. El tratamiento de las lesiones del ligamento lunotriquetral abarca diferentes técnicas con resultados poco reproducibles. La reconstrucción ligamentosa mediante un injerto tendinoso ha mostrado resultados favorables, aunque la realización de amplios abordajes conlleva una recuperación más lenta y menor movilidad articular por el excesivo tejido cicatricial. El objetivo de este estudio es describir la realización en cadáver de una ligamentoplastia lunotriquetral y de los estabilizadores secundarios de forma mínimamente invasiva, y su aplicación en un caso clínico representativo.

Material y Método Estudio preliminar de seis especímenes en el que se realizó de forma consecutiva una ligamentoplastia lunotriquetral y de los estabilizadores secundarios por medio de un injerto tendinoso libre con asistencia artroscópica. Se procedió a la recreación de la lesión completa del ligamento y valoración de la inestabilidad lunotriquetral según la clasificación de Geissler y el test Ballottement artroscópico. Se describe la técnica quirúrgica, la estabilidad ligamentosa tras la realización de la ligamentoplastia, y la disección anatómica posterior, valorando las estructuras anatómicas susceptibles de lesión yatrogénica. Se describe también la aplicación de la técnica en un caso, comparando los parámetros clínicos pre y postprocedimiento: balance articular, fuerza, dolor, y la versión corta del cuestionario de discapacidades del brazo, hombro y mano (Quick Disabilities of the Arm, Shoulder and Hand, QuickDASH, en inglés).

Resultados Las ligamentoplastias realizadas mostraron la recuperación de la estabilidad del intervalo lunotriquetral valorado según la clasificación de Geissler y el test de ballottement artroscópico. En la disección de los especímenes, no se encontraron lesiones yatrogénicas en tendones ni en las superficies articulares mediocarpiana y radiocarpiana. Las distancias medias entre los túneles óseos y los nervios más próximos fueron de $7.3 \mathrm{~mm}$ para la rama sensitiva cubital, de $3.6 \mathrm{~mm}$ para el nervio interóseo posterior, y de $4.5 \mathrm{~mm}$ para el paquete vasculonervioso cubital. No se observaron fracturas en los huesos tunelizados. En el caso clínico expuesto, se mejoró la fuerza y el dolor preoperatorio aunque con una disminución leve de la movilidad articular de la muñeca (15\% respecto a la contralateral) a los 6 meses de la intervención.

Conclusiones La ligamentoplastia lunotriquetral descrita puede contribuir a la restauración biomecánica del carpo y ser una alternativa reconstructiva en casos seleccionados. Su ejecución mediante técnicas mínimamente invasivas, y la utilización de un injerto tendinoso libre junto con la realización de rehabilitación específica deben considerarse para optimizar el resultado. 


\section{Introduction}

Regarding dissociative carpal instabilities, those caused by rupture of the lunotriquetral ligament have been eclipsed for different reasons, including the lack of striking acute radiological signs and the low specificity of the clinical symptoms and tests for their evaluation.

There is a current interest in the arthroscopic treatment of injuries to the intrinsic and extrinsic ligaments of the wrist, as shown by the increased number of publications and the development of minimally-invasive techniques who main goal is anatomical reconstruction. ${ }^{1}$ As in similar ligamentoplasties, ${ }^{2}$ these techniques require training and evaluation in cadaveric specimens before any clinical application.

The first objective of the present study was to design a lunotriquetral and radiotriquetral dorsal arthroscopic ligamentoplasty in cadaveric specimens to assess the efficacy and safety of the procedure. Our second objective was to evaluate its clinical application in a representative case. The hypothesis was that ligamentoplasty can result in lunotriquetral stability while sparing neighboring tissues and structures.

\section{Material and Methods}

\section{Indications and contraindications}

Reconstruction of the lunotriquetral ligament is indicated in patients who present the symptomatology and a clinical examination indicating a chronic, grade-III or -IV lesion (per the Geissler classification ${ }^{3}$ ), with failure of the conservative treatment, and altered carpal kinematics due to claudication of the secondary stabilizers. This procedure is contraindicated in cases of injuries with degenerative arthropathy and/or non-reducible instabilities.

\section{Surgical Anatomy}

Previous anatomical studies ${ }^{4}$ have indicated the anatomopathological properties of the lunotriquetral ligament and its mechanism of carpal biomechanical alteration by triggering a volar intercalated segment instability (VISI). In order for this to happen, there must be an alteration in the lunotriquetral ligament and its secondary stabilizers, as well as in the dorsal radiocarpal and intercarpal ligaments. A bonetendon-bone plasty with a free flexor carpi radialis or palmaris longus hemitendon was selected, which enables the reconstruction of the volar region of the lunotriquetral ligament, its most important portion, ${ }^{5}$ and of the dorsal radiocarpal ligament as an extrinsic stabilizer. The technique was been performed through usual wrist arthroscopic portals and high resistance fixation systems (interference screws and harpoons) for early mobilization.

\section{Preliminary study in specimens}

A total of six cadaveric specimens were used to perform the technique and evaluate its efficacy and safety. The specimens were donated for scientific purposes and handled according to the standards of the practice. The research protocol was approved by the Ethics in Research Committee of Hospital

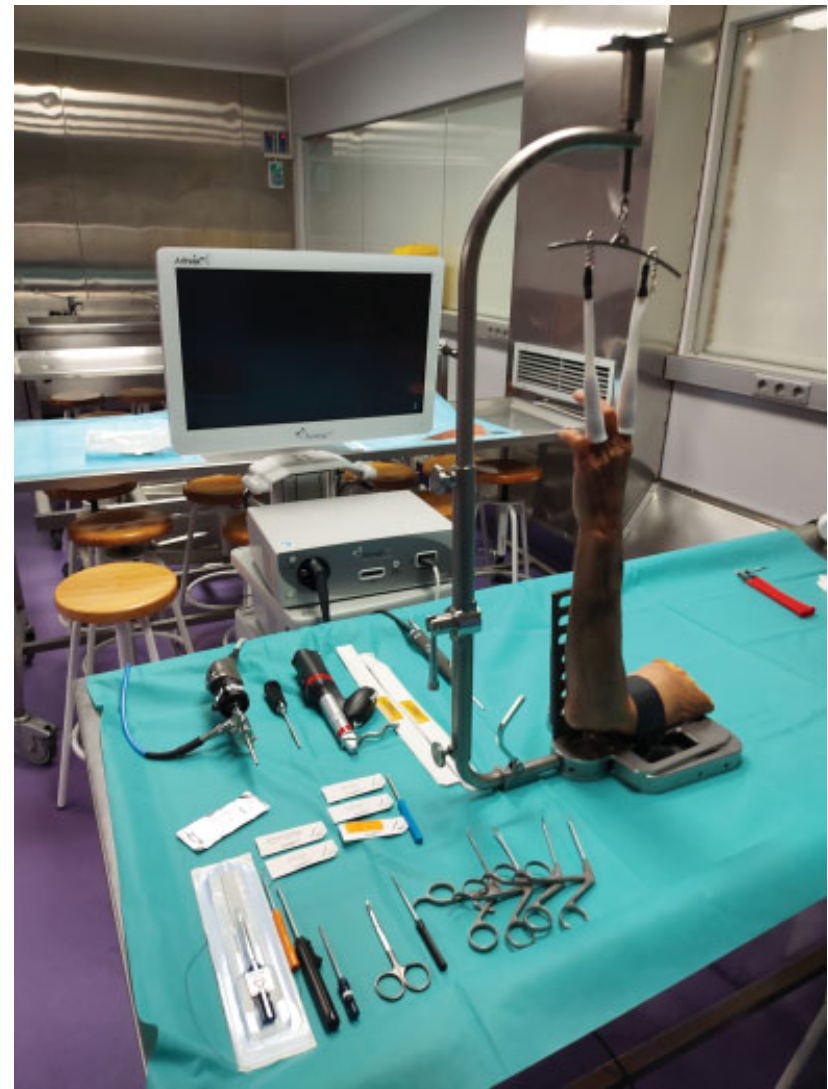

Fig. 1 Preparation and placement of the cadaveric specimen in the dissection room.

Universitario de Bellvitge, under registration number PR 384/18 (CSI 18/62).

A forearm stabilization and wrist traction system was used (Arc Wrist Tower, Acumed, Hillsboro, OR, US) (-Figure 1). The surgical technique described in the corresponding section was followed, except for the fact that it was performed on Geissler grade-IV lunotriquetral lesions created during the same act by complete ligament section. After reconstruction, the degree of stabilization was assessed per the Geissler classification system ${ }^{3}$ and the ballottement test. $^{6}$ Finally, the anatomical dissection of the specimen was performed to check the integrity of the structures around the ligamentoplasty site and to specifically assess the distances to the three structures most susceptible to iatrogenic injury: the dorsal branch of the ulnar nerve (distance from the dorsal exit of the pyramidal bone tunnel), the ulnar neurovascular bundle (distance from the volar pyramidal tunnel), and the posterior interosseous nerve (distance from the lunate dorsal tunnel).

\section{Clinical case and surgical technique}

A 40-year-old male patient, with a 1-year history of trauma, ulnar pain, and subjective loss of grip strength. The physical examination showed normal joint range of motion, decreased grip strength compared to the contralateral wrist (of $23 \mathrm{~kg}, 61 \%$ of the normal value), ulnar pain, and a positive Reagan test. ${ }^{7}$ The score on the shortened version of the Disabilities of the Arm, Shoulder and Hand questionnaire 
(QuickDASH) ${ }^{8}$ was of 35 , and pain was rated as 6 out of 10 per the Visual Analog Scale (VAS). Since no pathological alterations were observed in the initial plain radiographs, the patient underwent conservative treatment, consisting of immobilization with orthoses followed by physical therapy. There was no improvement after two months of therapy. A magnetic resonance imaging (MRI) scan showed no pathological findings. Due to the lack of clinical improvement, a diagnostic arthroscopy was performed, and it revealed a grade-III lunotriquetral instability. In a second intervention, before the approval for inclusion in this research protocol, a lunotriquetral ligamentoplasty was performed.

After an axillary block, preparation of the sterile field, and a proximal ischemia cuff, the limb was positioned using a wrist traction system (Arthrex, Naples, FL, US). The following classic arthroscopic dorsal radiocarpal portals were performed: 3-4, 4-5, radial midcarpal, ulnar midcarpal, and central volar portals. ${ }^{9}$ A palpation hook was used to confirm the presence of grade-III or grade-IV lunotriquetral instability and the attenuation of the dorsal extrinsic ligaments. Using a $2.9-\mathrm{mm}$ synoviotome, the redundant synovial tissue from the dorsal facets of the lunate and pyramidal bones was removed for proper visualization.

We proceeded to extract the free graft using the palmaris longus or a flexor carpi radialis hemitendon with $3 \mathrm{~mm}$ to $4 \mathrm{~mm}$ in thickness and $10 \mathrm{~cm}$ in length. In the cases in which the palmaris longus is present, it may be harvested using the same incision performed for the central volar portal.

Under scopic control and using an external guide (SLAM guide, Arthrex) or a freehand approach, the pyramidal bone tunnel was prepared with a $3.0-\mathrm{mm}$ cannulated drill bit (BioTenodesis Screw Kit $3 \mathrm{~mm} \times 8 \mathrm{~mm}$, Arthrex), from the posterior-internal (subcutaneous) edge to the anterior-external edge (-Figure 2). A straight suture retriever (SutureLasso, Arthrex) was introduced from the dorsal region of the tunnel up to the central volar portal. After enlarging the 4-5 portal and performing a miniarthrotomy, a lunate bone tunnel was prepared in a posteroanterior direction, perpendicular to the long axis of the wrist; a second suture retriever was passed through this tunnel in the posteroanterior direction (-Figure 2).

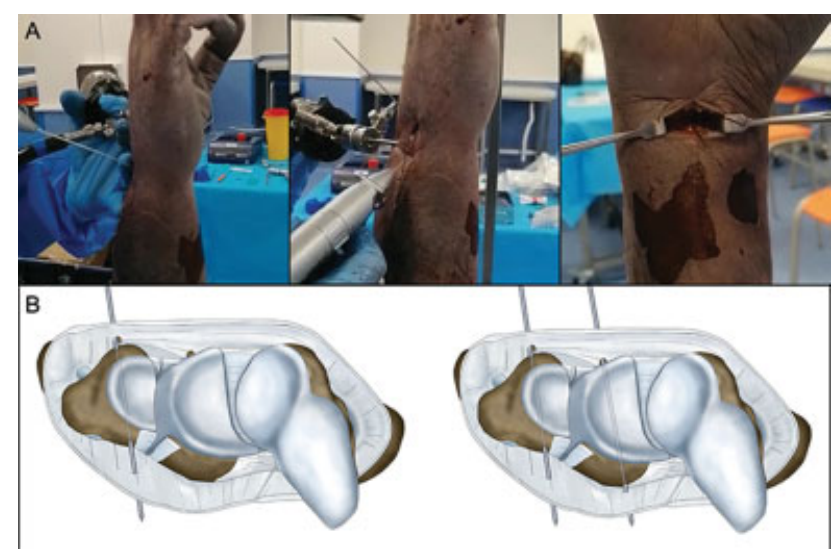

Fig. 2 Pyramidal and lunate tunnel preparation.

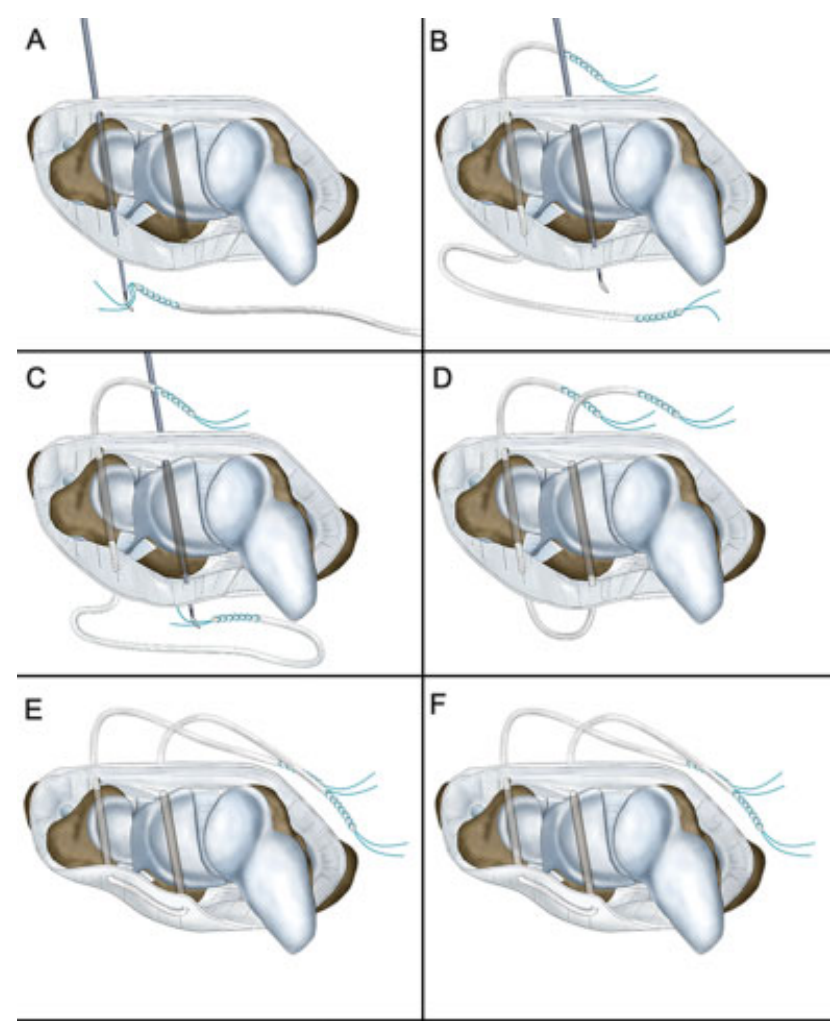

Fig. 3 Passage of the free plasty through the tunnels.

The free graft plasty was prepared with 4-0, high-strength suture (Fiberloop, Arthrex) at the ends that were loaded into the suture retrievers to pass the plasty through the tunnels (-Figure 3). The plasty was fixed with a $3-\mathrm{mm} \times 8-\mathrm{mm}$ interferthence screw (Bio-Tenodesis Screw System) in each tunnel in the anteroposterior direction, sustaining the plasty with traction on both ends; as such, the volar portion of the lunotriquetral ligament was reconstructed with adequate tension. The suture was retrieved through the dorsal aspect of the 4-5 portal to perform a dorsal capsular reinforcement following the direction of the dorsal radiocarpal and radiolunate ligaments (-Figure 4). Both were fixed on the dorsal edge of the radius through the 4-5 portal, widening its incision until the distal edge of the radius was visible. Fixation was made with a 1.4-mm harpoon (JuggerKnot, Zimmer Biomet, Warsaw, IN, US) or a posteroanterior tunnel with an interference screw. At the end of the procedure, the stability of the construct was evaluated with a palpation hook and the arthroscopic ballottement maneuver (-Figure 5).

\section{Postoperative period}

This type of reconstructive surgery is followed by a two-week immobilization period with a dorsal antebrachiopalmar splint. Subsequently, the splint is replaced by an orthosis that enables initial passive joint mobilization exercises. After the sixth week, the orthosis is removed, and the exercise load, increased. Potentiation and proprioceptive work of the extensor carpi ulnaris is emphasized because this is the only 


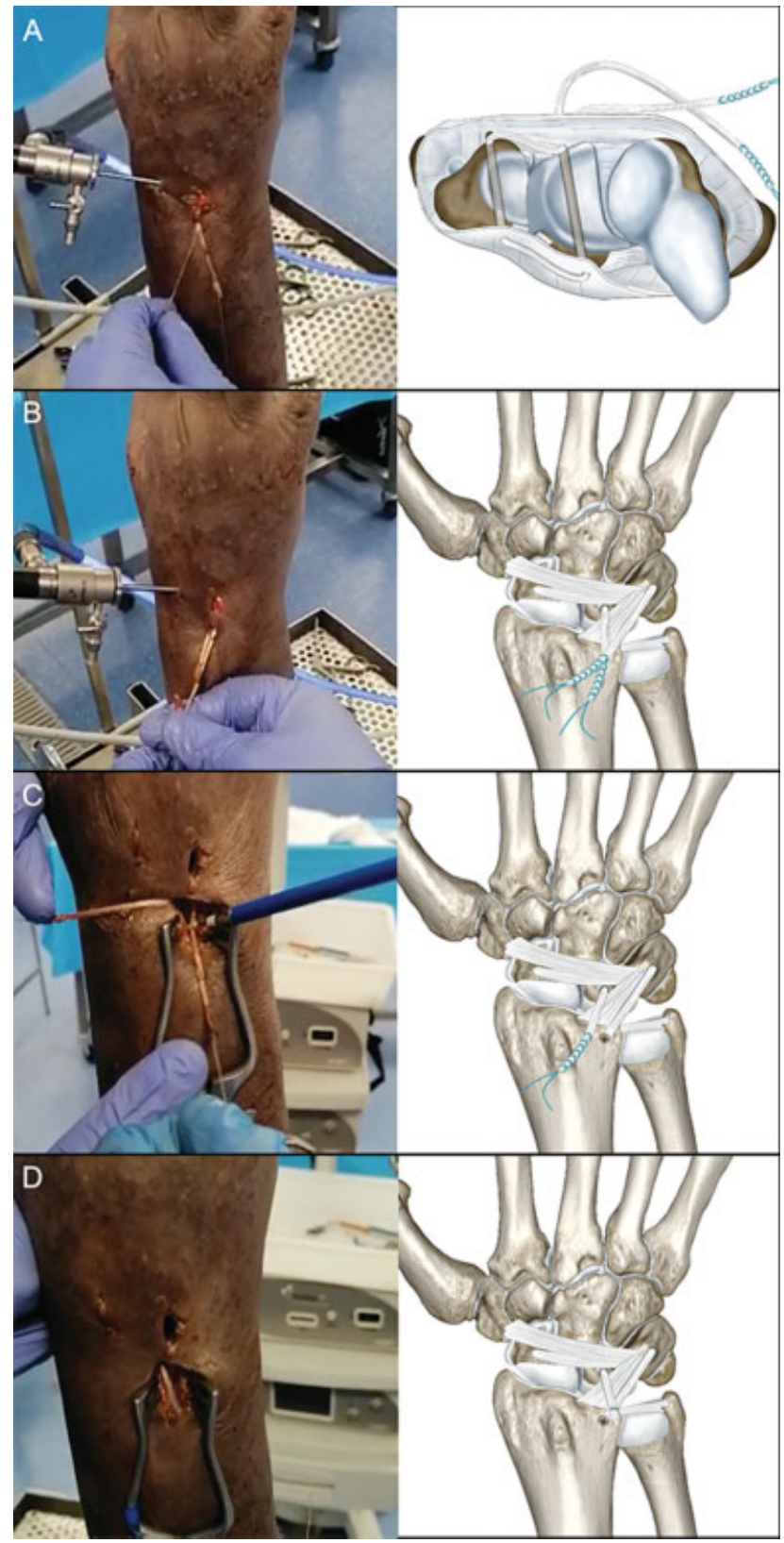

Fig. 4 Reconstruction and fixation of the secondary stabilizers in the distal radius.

muscle able to avoid pyramidal flexion and supination, ${ }^{10}$ and it contributes to the dynamic stabilization of the carpus.

\section{Results}

Restoration of lunotriquetral ligamentous stability has been observed in all ligamentoplasties performed in cadaveric specimens and in the clinical case, both on the arthroscopic ballottement test and in the evaluation with a palpation hook (-Table 1).

In the postprocedural anatomical dissection of the cadaveric specimens, no iatrogenic lesions were observed in extensor tendons, flexor tendons, or the ulnar neurovascular bundle; in addition, there were no intraoperative fractures or damages to the midcarpal and radiocarpal joint surfaces. The

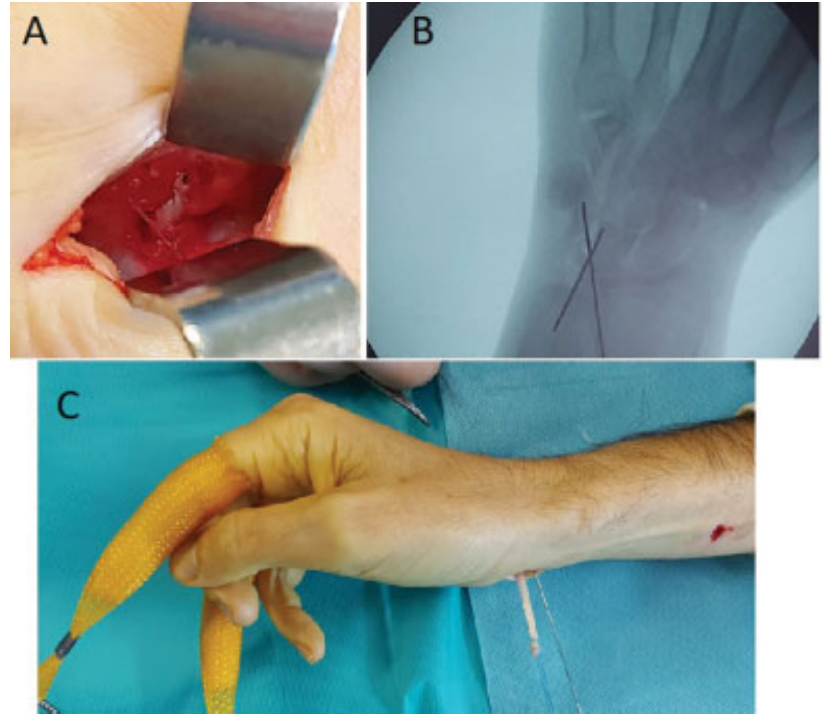

Fig. 5 Intraoperative aspects of the clinical case. (A) Central volar portal, reconstruction of the volar portion of the ligament, and fixation with interference screws. (B) Intraoperative endoscopy to identify the correct direction of the tunnels. (C) Suture retriever passing through bone tunnels and plasty recovery on the dorsal side.

mean distance between significant at-risk structures was of $7.3 \mathrm{~mm}$ from the dorsal pyramidal tunnel to the ulnar sensory branch, $3.6 \mathrm{~mm}$ from the dorsal lunate tunnel to the posterior interosseous nerve, and $4.5 \mathrm{~mm}$ from the volar pyramidal tunnel to the ulnar nerve bundle ( - Table 1 ).

Our patient presented a satisfactory postoperative improvement in pain and grip strength $(31 \mathrm{~kg}, 81 \%$ of the normal values). Six months after the intervention, the score on the QuickDASH was of 14 , and the VAS score was 2 . Regarding joint mobility of the wrist, a decrease of $10 \%$ to $15 \%$ was observed compared to the contralateral wrist in flexion-extension and radioulnar deviation.

\section{Discussion}

First, the present work proposes an alternative for the minimally-invasive reconstruction of the lunotriquetral ligament and its secondary stabilizers. Secondly, its design tries not only to reproduce the anatomy but also to counteract the pathological and mechanical aspects of the instability of the intercalated segment. Third, the process of development and evaluation of the technique in cadaveric specimens provides safety and efficacy for its clinical application.

The current standard in reconstructive surgery is minimal surgical aggression, and the techniques must meet this requirement. Chronic rupture of the lunotriquetral ligament can be solved with different techniques; however, its reconstruction with a tendon plasty should be the golden standard in selected cases. As such, a similar technique ${ }^{1}$ with arthroscopic assistance was used in two patients with satisfactory outcomes. This technique presents three differences. The first is the use of the extensor carpi ulnaris tendon as a donor; in published studies ${ }^{11}$ on lunotriquetral stabilization, the palmaris longus or flexor carpi radialis hemitendon is 
Table 1 Description of pre- and postligamentoplasty stability. Distance of at-risk structures from bone tunnels

\begin{tabular}{|c|c|c|c|c|c|c|c|}
\hline Case & $\begin{array}{l}\text { Ballottement, } \\
\text { preprocedural }\end{array}$ & $\begin{array}{l}\text { Ballottement, } \\
\text { postprocedural }\end{array}$ & $\begin{array}{l}\text { Geissler, } \\
\text { preprocedural }\end{array}$ & $\begin{array}{l}\text { Geissler, } \\
\text { postprocedural }\end{array}$ & $\begin{array}{l}\text { Distance } \\
\text { from the } \\
\text { sensory } \\
\text { branch } \\
\text { of the } \\
\text { ulnar } \\
\text { nerve } \\
(\mathrm{mm})\end{array}$ & $\begin{array}{l}\text { Distance } \\
\text { from the } \\
\text { posterior } \\
\text { interosseus } \\
\text { nerve } \\
(\mathrm{mm})\end{array}$ & $\begin{array}{l}\text { Distance } \\
\text { from the } \\
\text { ulnar } \\
\text { neurovascular } \\
\text { bundle } \\
(\mathrm{mm})\end{array}$ \\
\hline 1 & $* * *$ & $*$ & IV & 1 & 7 & 3 & 6 \\
\hline II & $* * *$ & * & IV & 1 & 9 & 4 & 4 \\
\hline III & $* * *$ & * & IV & 0 & 5 & 5 & 5 \\
\hline IV & $* * *$ & $*$ & IV & 1 & 3 & 4 & 3 \\
\hline $\mathrm{V}$ & $* * *$ & * & IV & 0 & 9 & 2 & 4 \\
\hline \multirow[t]{2}{*}{ VI } & $* * *$ & $*$ & IV & 1 & 11 & 4 & 5 \\
\hline & & & & & 7.33 & 3.6 & 4.5 \\
\hline
\end{tabular}

Note: ${ }^{*}$ mild instability; ${ }^{* *}$ moderate instability; ${ }^{* * *}$ severe instability.

preferred. The second difference is the use of exclusive instrumentation for the technique, which prevents its reproduction. Finally, there was no anatomical study in cadaveric specimens to maximize the protection of at-risk structures.

As in other types of injuries to intrinsic ligaments, the time elapsed since the injury influences the indication of surgical treatment. In cases of acute injuries with a native ligament with healing potential, satisfactory outcomes have been observed in more than $80 \%$ of the cases with simpler techniques, including debridement and fixation with Kirschner wires, volar capsulodesis, or direct repair with harpoons. ${ }^{12}$ The indication for a ligamentoplasty should be compared with the indication for a lunotriquetral arthrodesis due to the chronic nature of the lesion. For arthrodesis, the publications $^{13}$ report pseudoarthrosis rates higher than $50 \%$ and a decrease in joint range of motion of up to $40 \%$, which has made it a controversial procedure. This aspect, added to the satisfactory outcomes of ligamentoplasties either with an open approach ${ }^{14}$ or arthroscopic assistance, ${ }^{1}$ should be considered for treatment indication.

In recent years, an exponential development of wrist arthroscopic techniques has been observed, and the repair or reconstruction of the most important players in ligament stability has been described. As noted in the preliminary study with cadaveric specimens, there are anatomical structures a few millimeters away, and their injury may compromise the outcomes; the posterior interosseous nerve would be at the highest risk of injury during the completion of the lunate tunnel, and, to avoid it, a 4-5 portal expansion and its protection are recommended. Specific external guides should also be considered to avoid iatrogenic damage during the creation of the bone tunnels; in any case, several fluoroscopic projections may prevent iatrogenic injuries. The reported rate of complications decreases after 25 arthroscopies/year and more than 5 years of experience in this type of procedure. ${ }^{15}$ For this reason, similar training is recommended prior to the clinical application of the described technique.
In conclusion, arthroscopy-assisted lunotriquetral ligamentoplasty may be an option for the treatment of chronic instabilities with or without loss of the intercalated segment attachment. As in partial scapholunate ligament lesions, most injuries go unnoticed and cause functional limitation; and arthroscopy is an important tool for the diagnosis and treatment. At the moment, these are rare lesions, so further work is required to clarify the best treatment algorithm for them.

\section{Conflict of Interests}

The authors have no conflict of interests to declare.

\section{References}

1 Haugstvedt JR, Rigó IZ. Arthroscopic Assisted Reconstruction of LT-Ligament: A Description of a New Technique. J Wrist Surg 2021;10(01):2-8

2 Corella F, Del Cerro M, Larrainzar-Garijo R, Vázquez T. Arthroscopic ligamentoplasty (bone-tendon-tenodesis). A new surgical technique for scapholunate instability: preliminary cadaver study. J Hand Surg Eur Vol 2011;36(08):682-689

3 Geissler WB, Freeland AE, Savoie FH, McIntyre LW, Whipple TL. Intracarpal soft-tissue lesions associated with an intra-articular fracture of the distal end of the radius. J Bone Joint Surg Am 1996; 78(03):357-365

4 Viegas SF, Patterson RM, Peterson PD, et al. Ulnar-sided perilunate instability: an anatomic and biomechanic study. J Hand Surg Am 1990;15(02):268-278

5 Ritt MJ, Bishop AT, Berger RA, Linscheid RL, Berglund LJ, An KN. Lunotriquetral ligament properties: a comparison of three anatomic subregions. J Hand Surg Am 1998;23(03): 425-431

6 Ocampos Hernández M, Corella Montoya F, Del Cerro Gutiérrez M, Del Campo Cereceda B. Inestabilidad lunopiramidal Rev Iberam Cir mano. 2016;44(02):143-152

7 Reagan DS, Linscheid RL, Dobyns JH. Lunotriquetral sprains. J Hand Surg Am 1984;9(04):502-514

8 Gummesson C, Ward MM, Atroshi I. The shortened disabilities of the arm, shoulder and hand questionnaire (QuickDASH): validity and reliability based on responses within the full-length DASH. BMC Musculoskelet Disord 2006 May 18;7:44 
9 Corella F, Ocampos M, Cerro MD, Larrainzar-Garijo R, Vázquez T. Volar Central Portal in Wrist Arthroscopy. J Wrist Surg 2016;5(01):80-90

10 Salva-Coll G, Garcia-Elias M, Leon-Lopez MM, Llusa-Perez M, Rodríguez-Baeza A. Role of the extensor carpi ulnaris and its sheath on dynamic carpal stability. J Hand Surg Eur Vol 2012;37(06):544-548

11 Harper CM, Iorio ML. Lunotriquetral Ligament Reconstruction Utilizing a Palmaris Longus Autograft. J Hand Surg Asian Pac Vol 2017;22(04):544-547

12 Moskal MJ, Savoie FH III, Field LD. Arthroscopic capsulodesis of the lunotriquetral joint. Clin Sports Med 2001;20(01):141-153, ix-X
13 Sennwald GR, Fischer M, Mondi P. Lunotriquetral arthrodesis. A controversial procedure. J Hand Surg [Br] 1995;20(06): 755-760

14 Shin AY, Weinstein LP, Berger RA, Bishop AT. Treatment of isolated injuries of the lunotriquetral ligament. A comparison of arthrodesis, ligament reconstruction and ligament repair. J Bone Joint Surg Br 2001;83(07):1023-1028

15 Leclercq C, Mathoulin CMembers of EWAS. Complications of Wrist Arthroscopy: A Multicenter Study Based on 10,107 Arthroscopies. J Wrist Surg 2016;5(04):320-326 